\section{Short-term Cyclic Cold Temperature Stress on Watermelon Yield}

\author{
Ahmet Korkmaz ${ }^{1}$ and Robert J. Dufault ${ }^{2}$ \\ Clemson University Coastal Research and Education Center, Department of \\ Horticulture, Clemson University, 2865 Savannah Highway, Charleston, \\ SC 29414-5332
}

Additional index words. Citrullus lanatus, Cucurbitaceae, cucurbits, chilling stress

\begin{abstract}
Watermelon [Citrullus lanatus (Thunb) Matsum. \& Nakai.] seedlings may be repeatedly exposed to temperatures alternating between almost freezing and optimum soon after field transplanting. 'Carnival', 'Crimson Sweet', 'Millionaire' and 'Crimson Trio' watermelon transplants were exposed to cold temperature stress at $2 \pm 1^{\circ} \mathrm{C}$ in a walkin cooler and then to $29 \pm 5^{\circ} \mathrm{C}$ in a greenhouse immediately before field planting to simulate temperature alternations that may occur after field transplanting. Cold-stressed transplants were field planted after all risk of ambient cold stress passed. In 1998, transplants were exposed to $2{ }^{\circ} \mathrm{C}$ from 9 hours to 54 hours, and in 1999 from 9 to 81 hours. Early yields of all cultivars, except Carnival, significantly decreased with increasing hours of cold stress in both years. Total yields of 'Carnival' decreased linearly in both years with a $10 \%$ yield reduction occurring from 14 to 15 hours of cold stress. 'Crimson Sweet' yields were reduced in 1999 only, with 16 hours of cold stress reducing yield $10 \%$.
\end{abstract}

More than half of the annual watermelon supply in the United States is consumed during the months of June and July (Mizelle, 1988) with prices declining during this time (Mizelle, 1985). Therefore, market demand necessitates that growers plant watermelons early in the season in order to achieve higher prices and greater profits.

Watermelons are very tender, warm season crops and are native to tropical and southern Africa (Bates and Robinson, 1995). Although environmental conditions in South Carolina are ideal for growing watermelons, early planting in March exposes the seedlings to risks of cold temperature damage for weeks before temperatures stabilize. Exposure of cucurbits to cold temperatures can cause low temperature injury in the form of stunted plant growth, wilting, necrotic lesions on leaves, and increased susceptibility to diseases and pathogens (Rikin et al., 1976; Sasson and Bramlage, 1981). Growth reductions may be caused by several factors including impaired photosynthesis, respiration, membrane integrity, and hormonal balance (Graham and Patterson, 1982). Low temperatures are known to reduce the growth of tomato (Lycopersicon esculentum Mill.) (Pardossi et al., 1988), corn (Zea mays L.) (Hetherington et al., 1983; Stamp, 1987), muskmelon (Cucumis melo L.) (Risser et al., 1978), watermelon (Bradow, 1990; Hassell, 1979) and cotton (Gossypium sp.) (Stewart and Guinn, 1969). However, the effects of diurnal temperature changes on growth, subsequent plant performance, and yield are poorly documented. Dufault and

Received for publication 9 May 2001. Accepted for publication 8 Oct. 2001.

${ }^{1}$ Former Graduate Student; present address: Gaziosmanpasa Univ., Dept. of Horticulture, Tokat, Turkey, 60240.

${ }^{2}$ Professor
Melton (1990) found that exposure of tomato transplants to $2{ }^{\circ} \mathrm{C}$ for as long as $180 \mathrm{~h}$ did not quality. In our previous study, we found that yield of 'Carnival' watermelon decreased linearly as exposure to $2{ }^{\circ} \mathrm{C}$ increased from 0 to $81 \mathrm{~h}$ during seedling stage (Korkmaz and Dufault, 2001). However, because we only tested one cultivar in that study, it was unknown whether other watermelon cultivars would behave in a similar fashion. Therefore, our objective in this study was to determine the long-term effects of short-term cold stress at transplanting on the yield of four commercially popular watermelon cultivars including two seedless cultivars.

\section{Materials and Methods}

Two diploid ('Carnival' and 'Crimson Sweet') and two triploid ('Crimson Trio' and 'Millionaire') watermelon cultivars were evaluated in this study. 'Carnival', 'Crimson Sweet', and 'Crimson Trio' seeds were obtained from Rogers Brothers Seed Co. (Salinas, Calif.) and 'Millionaire' seeds from Harris Moran (Modesto, Calif.). Seed were planted with radicles pointing down in 5.4-cm deep cells $\left(57 \mathrm{~cm}^{3}\right)$ (Hummert Intl., Earth City, Mo.) filled with Metro Mix 300 growth medium (Grace Sierra Co., Milpitas, Calif.) on 21 Apr. 1998 and 14 Apr. 1999. The flats were covered with plastic sheets to retain moisture and placed in a germination room at $32{ }^{\circ} \mathrm{C}$ for $2 \mathrm{~d}$ then moved into a greenhouse where they were kept under natural photoperiod and $29 \pm$ $5{ }^{\circ} \mathrm{C}$ day $/ 20 \pm 5{ }^{\circ} \mathrm{C}$ night. Seedlings were watered as needed and fertilized twice with 50 $\mathrm{mg} \cdot \mathrm{L}^{-1}$ of Peters $20 \mathrm{~N}-8.6 \mathrm{P}-16.6 \mathrm{~K}$ (Scotts Co., Marysville, Ohio) water-soluble fertilizer.

Transplant cold stress started on 11 May and 30 Apr. and ended on 17 and 9 May in affect earliness, total productivity, and fruit 1998 and 1999, respectively. Eighteen-day old seedlings were exposed to $2{ }^{\circ} \mathrm{C}$ for $9 \mathrm{~h}$ for 1, 2, 4, and $6 \mathrm{~d}$ in 1998 and for 1, 2, 4, 6, and $9 \mathrm{~d}$ in 1999. Plants were moved into dark walkin coolers during the night hours, exposed to cold temperatures for nine hours (from 2100 $\mathrm{HR}$ to $0600 \mathrm{HR}$ ), and then returned to a warm greenhouse $\left(29^{\circ} \mathrm{C}\right)$. The total cumulative exposure to $2{ }^{\circ} \mathrm{C}$ ranged from $9 \mathrm{~h}$ to $54 \mathrm{~h}$ in 1998 and from $9 \mathrm{~h}$ to $81 \mathrm{~h}$ in 1999 . All cold stress treatments were timed to terminate on the same day to provide same-day field planting. Additionally, a control treatment, which included plants that remained in the greenhouse and never exposed to cold temperatures, was added to the experiment in both years. There were a total of five treatments in 1998 and six treatments in 1999. The experimental treatments were replicated three times in 1998 and four times in 1999 and all trays were arranged in a randomized complete-block design in the greenhouse.

Following cold stress, transplants were hand-transplanted into the field on 17 May 1998 and 10 May 1999 after all risk of ambient cold stress had passed. The soil type was Yonges loamy fine sand, Aquic Hapludult. Soil tests were taken from respective fields each year prior to planting and fertilized with $\mathrm{N}, \mathrm{P}$, and $\mathrm{K}$ at 175,75 , and $146 \mathrm{~kg} \cdot \mathrm{ha}^{-1}$, respectively, according to soil test recommendations. The field was limed with $\mathrm{Ca}$ and $\mathrm{Mg}$ at 146 and $88 \mathrm{~kg} \cdot \mathrm{ha}^{-1}$, respectively, from dolomitic limestone in both years. Beds on $1.8 \mathrm{~m}$ centers were fumigated with $75 \%$ methyl bromide and $25 \%$ chloropicrin at the rate of 450 $\mathrm{kg} \cdot \mathrm{ha}^{-1}$ and mulched with $0.032 \mathrm{~mm}$ black plastic. Treatment plots consisted of one row, 9.6-m long, containing eight plants. Each treatment plot was replicated in the field three times in 1998 and four times in 1999 in a randomized complete-block design. Plots were irrigated as needed. Tensiometers (20-cm deep) were used to determine $15 \%$ soil moisture depletion to signal the start of a 1-h irrigation cycle. Watermelons were sprayed with pesticides based on standard commercial recommendations (Cook, 1996).

Watermelons were harvested for the first time on 9 July 1998 and 7 July 1999 and these fruit were classified as early yield. Second and third harvests were made on 17 and 23 July in 1998. In 1999, the experiment was terminated after the second harvest on 20 July 1999. On the last harvest, all fruit were stripped from all plants. The minimum marketable weight in this study was defined as $5 \mathrm{~kg}$. Each fruit was weighed and graded as marketable or cull according to USDA standards (U.S. Dept. of Agriculture, 1978). Watermelons that weighed $<5 \mathrm{~kg}$ or misshapen were classified as cull.

Data were analyzed by harvest date and also pooled over the entire harvest season each year to determine the effects of cold temperature stress on earliness and total productivity, respectively. Polynomial regression analysis was performed between yield variables and total hours of cold exposure to determine the significance and strength of relationships. We chose a $10 \%$ yield reduction as the maximum tolerable yield reduction permissible before yield reduction was considered unacceptable 
commercially. To calculate this, the intercept of the regression equation was equivalent to the yield of noncold-stressed plants. If the yield of any treatment was $<90 \%$ of noncoldstressed plants, that particular treatment suffered a $10 \%$ yield reduction. The same procedure was used to determine the tolerance level for $20 \%$ yield reduction if a $10 \%$ tolerance level is considered too stringent.

\section{Results}

Cold stress vs. earliness. Cold stress affected earliness similarly for all watermelon cultivars, except 'Carnival'. As cold stress increased in both years, early yield of 'Crimson Sweet', 'Millionaire', and 'Crimson Trio' decreased linearly, but 'Carnival' was unaffected (Table 1). Cold stress did not affect early fruit weight of any cultivar in either year (data not shown). 'Crimson Sweet' and 'Crimson Trio' plants exposed to $2^{\circ} \mathrm{C}$, produced fewer fruit per plot as cold stress increased, which, in turn, reduced the early yields linearly in both years. 'Crimson Sweet' plants exposed to $54 \mathrm{~h}$ of cold stress in 1998 yielded $79 \%$ less than control plants and, furthermore, plants exposed to $81 \mathrm{~h}$ of cold did not produce any early yield. Similarly 'Crimson Trio', seedlings exposed to greatest hours of cold stress in both years did not yield early fruit. Although the number of early 'Millionaire' fruit decreased with increasing hours of cold stress only in 1999, early yields in weight decreased linearly in both years with increasing cold stress with plants exposed to highest levels of cold stress yielding $79 \%$ and 85\% less than control plants in 1998 and 1999 , respectively.
Cold stress vs. total yield. 'Millionaire' was the only cultivar in which cold stress decreased individual fruit weight in 1998. As cold stress increased from 0 to $54 \mathrm{~h}$, 'Millionaire' fruit weight decreased, but not in 1999 (Table 2). Furthermore, 'Millionaire' and 'Crimson Trio' yields tended to decrease by $45 \%$ and $40 \%$, respectively, with increasing hours of cold stress in both years, but this was nonsignificant. Similarly, the number of 'Carnival' fruit/plot decreased by $26 \%$ and $51 \%$ in 1998 and 1999 as cold stress hours increased, respectively, but this was also nonsignificant. 'Carnival' total yields, however, decreased linearly by $31 \%$ and $53 \%$ in 1998 and 1999, respectively, with increasing hours of cold stress. Cold stress 'Crimson Sweet' plants in 1999 produced less fruit/plot in a linear manner as length of cold stress increased, which subsequently reduced total yield by $40 \%$, but this event did not happen in 1998 . Cold stress did not affect cull yield of any cultivar in either year (data not shown).

\section{Discussion}

Only a few available studies describe the effect of low temperatures on watermelon growth and yield. Hassell (1979) found that exposing 2-week-old 'Sugar Baby' watermelon seedlings to $1{ }^{\circ} \mathrm{C}$ during the nighttime $(9 \mathrm{~h})$ for 8 d reduced yield $20 \%$ compared to plants exposed to $18{ }^{\circ} \mathrm{C}$ during nights. Hall et al. (1993) reported that 'Crimson Sweet' watermelons planted in Georgia on 28 Apr. yielded more than those planted on $1 \mathrm{Apr}$., due to $12^{\circ} \mathrm{C}$ warmer soil temperatures at later planting date and that the risk of cold damage with early plantings makes later transplanting more desirable.

In a previous study, we found that, although 'Carnival' early yields were unaffected, total yields decreased linearly as cold stress increased from $0 \mathrm{~h}$ to $38 \mathrm{~h}$ to $40 \mathrm{~h}$, reducing yield by $10 \%$ (Korkmaz and Dufault, 2001). The results reported in the present study are similar to our previous work, indicating that $14 \mathrm{~h}$ and $15 \mathrm{~h}$ of cold stress reduced the yield of 'Carnival' watermelons by $10 \%$ in 1998 and 1999, respectively (Fig. 1). In addition, 'Crimson Sweet' yields also decreased $10 \%$ with exposure to $16 \mathrm{~h}$ of cold in 1999 (Fig. 2), but there was not a significant relationship between cold stress hours and yield in 1998. The strengths of the relationships $\left(R^{2}\right)$ between hours of cold stress and yield of 'Carnival' and 'Crimson Sweet' were low due to high experimental error (data not shown). The plants were apparently affected by a wide range of uncontrolled environmental factors in the field such as pathogens and insects, which ultimately diluted the strength of relationship between cold stress and yield.

Researchers customarily choose a probability level of $5 \%$ or $1 \%$ to judge significance of F-tests. If a $10 \%$ difference in yield is considered economically important, using a more liberal $P$-value may be justified in some cases (Marini, 1999). Total yields of 'Millionaire' and 'Crimson Trio' were unaffected by as much as $81 \mathrm{~h}$ of cold stress at the $5 \%$ probability level, but choice of a probability level higher than $5 \%$ would have indicated significant yield reductions. Since we used the conventional probability levels used

Table 1. The relationship between cold stress hours and early yield of watermelon cultivars.

\begin{tabular}{|c|c|c|c|c|c|c|c|c|c|c|c|c|c|c|c|c|}
\hline \multirow{3}{*}{$\begin{array}{l}\text { Cold stress } \\
\text { (h) }\end{array}$} & \multicolumn{4}{|c|}{ Carnival } & \multicolumn{4}{|c|}{ Crimson Sweet } & \multicolumn{4}{|c|}{ Millionaire } & \multicolumn{4}{|c|}{ Crimson Trio } \\
\hline & \multicolumn{2}{|c|}{ Fruit/plot } & \multicolumn{2}{|c|}{ Yield (kg/plot) } & \multicolumn{2}{|c|}{ Fruit/plot } & \multicolumn{2}{|c|}{ Yield (kg/plot) } & \multicolumn{2}{|c|}{ Fruit/plot } & \multicolumn{2}{|c|}{ Yield (kg/plot) } & \multicolumn{2}{|c|}{ Fruit/plot } & \multicolumn{2}{|c|}{ Yield (kg/plot) } \\
\hline & 1998 & 1999 & 1998 & 1999 & 1998 & 1999 & 1998 & 1999 & 1998 & 1999 & 1998 & 1999 & 1998 & 1999 & 1998 & 1999 \\
\hline 0 & 4.3 & 1.3 & 32.3 & 10.8 & 3.3 & 2.0 & 25.9 & 14.8 & 2.0 & 1.5 & 17.3 & 10.4 & 2.0 & 1.5 & 13.4 & 10.6 \\
\hline 18 & 3.7 & 1.3 & 29.8 & 12.4 & 1.0 & 1.5 & 7.1 & 11.3 & 1.3 & 1.3 & 8.5 & 8.0 & 0.7 & 2.0 & 4.8 & 13.8 \\
\hline 36 & 2.0 & 2.3 & 14.3 & 20.2 & 1.0 & 1.3 & 7.4 & 13.0 & 1.0 & 0.8 & 7.3 & 6.4 & 0.7 & 0.3 & 4.4 & 1.5 \\
\hline 54 & 1.7 & 1.3 & 17.2 & 12.5 & 0.7 & 1.0 & 5.4 & 7.1 & 0.7 & 0.5 & 3.7 & 3.3 & 0.0 & 0.3 & 0.0 & 1.3 \\
\hline 81 & $--^{\mathrm{z}}$ & 1.0 & --- & 8.3 & --- & 0.0 & --- & 0.0 & --- & 0.3 & --- & 1.6 & --- & 0.0 & --- & 0.0 \\
\hline \multicolumn{17}{|l|}{ Regression } \\
\hline Significance & $\mathrm{L}^{*}$ & NS & NS & NS & $\mathrm{L}^{*}$ & $\mathrm{~L}^{* *}$ & $\mathrm{~L}^{*}$ & $\mathrm{~L}^{*}$ & NS & $\mathrm{L}^{*}$ & $\mathrm{~L}^{*}$ & $\mathrm{~L}^{*}$ & $\mathrm{~L}^{*}$ & $\mathrm{~L}^{*}$ & $\mathrm{~L}^{*}$ & $\mathrm{~L}^{*}$ \\
\hline$R^{2}$ & 0.42 & -- & -- & -- & 0.33 & 0.32 & 0.33 & 0.26 & -- & 0.23 & 0.31 & 0.23 & 0.40 & 0.22 & 0.38 & 0.22 \\
\hline$P$-value & 0.02 & 0.35 & 0.06 & 0.60 & 0.05 & 0.01 & 0.05 & 0.02 & 0.08 & 0.03 & 0.05 & 0.03 & 0.03 & 0.04 & 0.03 & 0.04 \\
\hline
\end{tabular}

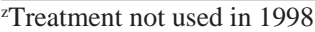

Ns, *, ** Nonsignificant or significant at $P<0.05$ or 0.01 , respectively.

Table 2. The relationship between cold stress hours and total yield of watermelon cultivars

\begin{tabular}{|c|c|c|c|c|c|c|c|c|c|c|c|c|c|c|c|c|c|c|}
\hline \multirow{3}{*}{$\begin{array}{l}\text { Cold stress } \\
\text { (h) }\end{array}$} & \multicolumn{4}{|c|}{ Carnival } & \multicolumn{4}{|c|}{ Crimson Sweet } & \multicolumn{6}{|c|}{ Millionaire } & \multicolumn{4}{|c|}{ Crimson Trio } \\
\hline & \multicolumn{2}{|c|}{ Fruit/plot } & \multicolumn{2}{|c|}{ Yield (kg/plot) } & \multicolumn{2}{|c|}{ Fruit/plot } & \multicolumn{2}{|c|}{ Yield (kg/plot) } & \multicolumn{2}{|c|}{ Fruit wt (kg) } & \multicolumn{2}{|c|}{ Fruit/plot } & \multicolumn{2}{|c|}{ Yield (kg/plot) } & \multicolumn{2}{|c|}{ Fruit/plot } & \multicolumn{2}{|c|}{ Yield (kg/plot) } \\
\hline & 1998 & 1999 & 1998 & 1999 & 1998 & 1999 & 1998 & 1999 & 1998 & 1999 & 1998 & 1999 & 1998 & 1999 & 1998 & 1999 & 1998 & 1999 \\
\hline 0 & 18.6 & 20.5 & 165.1 & 170.1 & 16.0 & 18.5 & 125.0 & 141.6 & 8.3 & 7.2 & 16.3 & 16.0 & 132.5 & 118.3 & 12.7 & 15.8 & 90.5 & 115.0 \\
\hline 18 & 17.4 & 17.8 & 151.1 & 147.5 & 13.4 & 16.3 & 98.4 & 125.6 & 7.3 & 7.5 & 14.3 & 13.3 & 103.4 & 91.6 & 10.0 & 12.8 & 73.8 & 92.3 \\
\hline 36 & 15.0 & 14.5 & 128.4 & 114.2 & 14.7 & 14.5 & 124.8 & 114.0 & 7.1 & 7.5 & 12.3 & 14.0 & 88.1 & 98.7 & 10.0 & 11.0 & 67.5 & 76.9 \\
\hline 54 & 13.8 & 12.5 & 113.1 & 100.1 & 13.0 & 12.3 & 99.0 & 95.1 & 6.7 & 7.1 & 10.3 & 11.5 & 75.3 & 82.7 & 8.0 & 9.8 & 56.1 & 66.7 \\
\hline 81 & $---^{2}$ & 10.0 & --- & 79.1 & --- & 10.2 & --- & 85.2 & --- & 6.6 & --- & 9.5 & --- & 64.0 & --- & 10.0 & --- & 68.7 \\
\hline Regression & & & & & & & & & & & & & & & & & & \\
\hline Significance & NS & NS & $\mathrm{L}^{*}$ & $\mathrm{~L}^{*}$ & NS & $\mathrm{L}^{*}$ & NS & $\mathrm{L}^{*}$ & $\mathrm{~L}^{* *}$ & NS & NS & NS & NS & NS & NS & NS & NS & NS \\
\hline$R^{2}$ & --- & --- & 0.12 & 0.11 & --- & 0.08 & --- & 0.11 & 0.23 & --- & --- & --- & --- & ----- & --- & --- & --- & --- \\
\hline$P$-value & 0.14 & 0.06 & 0.05 & 0.04 & 0.68 & 0.05 & 0.54 & 0.05 & 0.01 & 0.23 & 0.29 & 0.32 & 0.19 & 0.26 & 0.32 & 0.30 & 0.28 & 0.24 \\
\hline
\end{tabular}

Treatment not used in 1998.

Ns, *, ** Nonsignificant or significant at $P<0.05$ or 0.01 , respectively. 


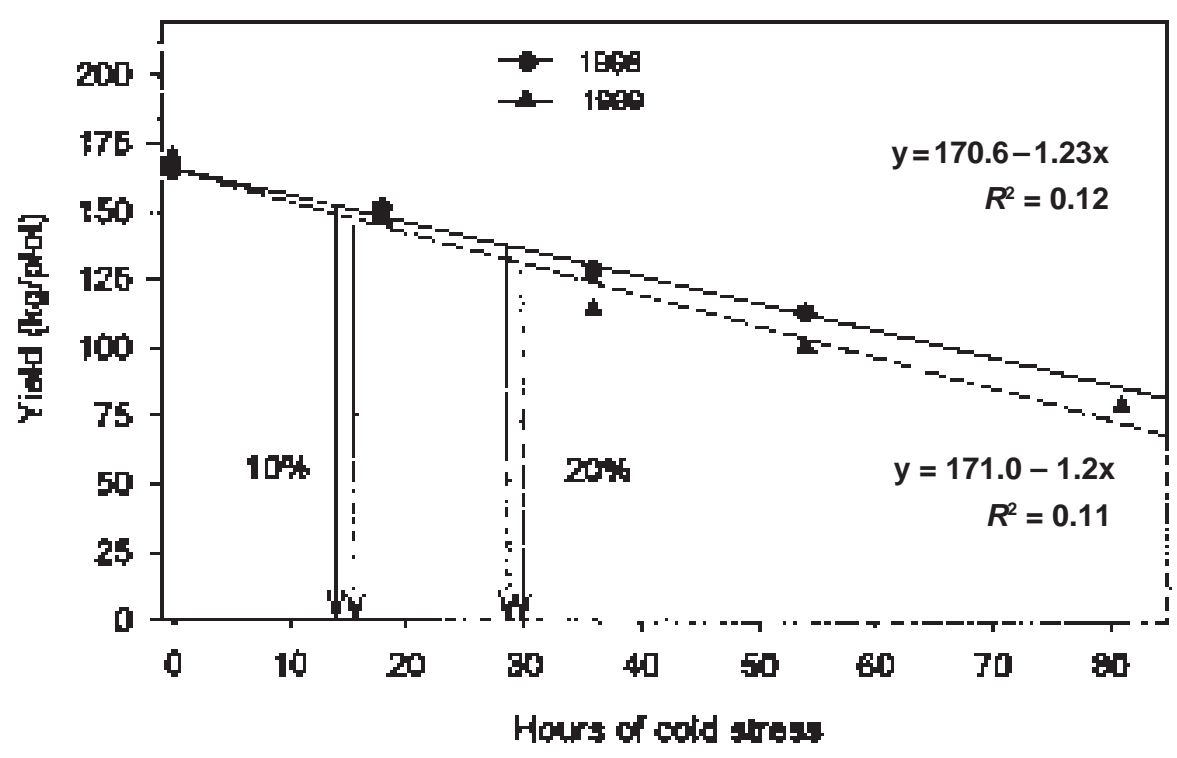

Fig. 1. Relationship between total cold hours and 'Carnival' watermelon total yield in 1998 and 1999. Regression analysis was performed on replication means $(n=3$ in 1998 and $n=4$ in 1999).

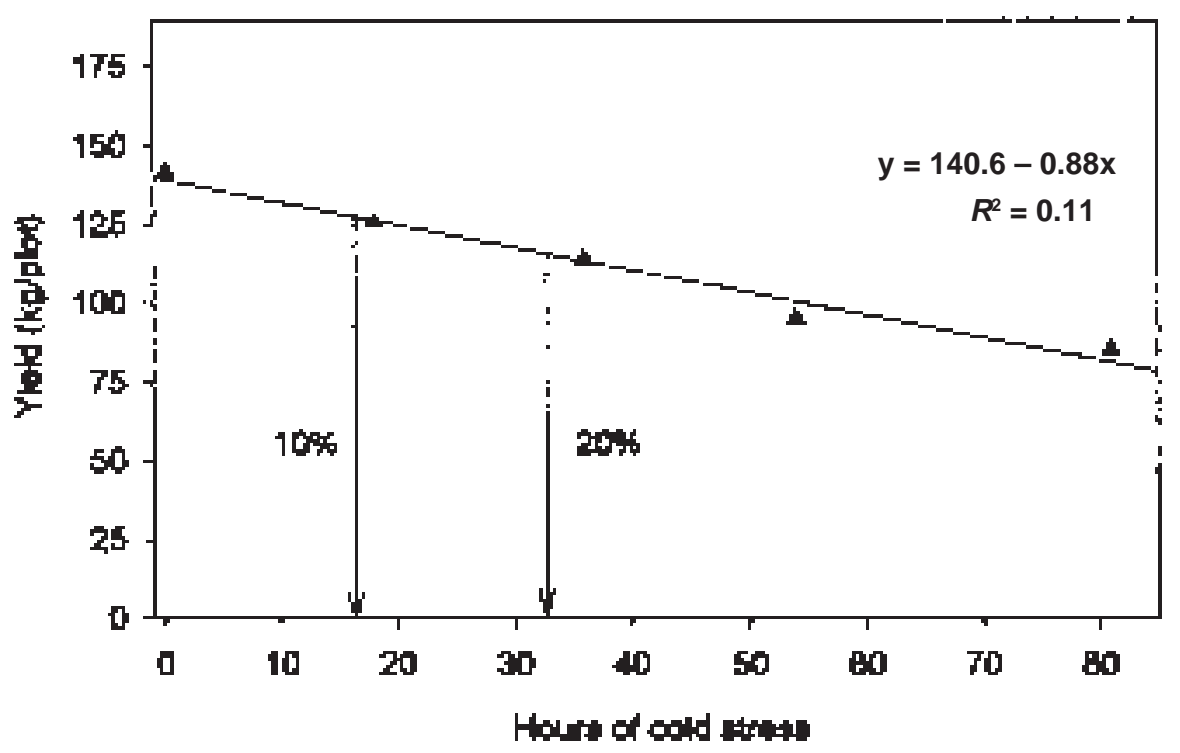

Fig. 2. Relationship between total cold hours and 'Crimson Sweet' watermelon total yield in 1999. Regression analysis was performed on replication means $(n=4)$.

widely in experimental research, we concluded that the reported mathematical decrease in yield was insignificant and not real. We propose that further research should consider using higher probability levels. The most appropriate probability levels should be based on the economic loss threshold a grower may find intolerable rather than using the stringent conventional probability levels that may be insensitive to yield reductions that could seriously impact a grower's profit.
Earliness is of paramount importance to growers to capture the highest prices for crops from early yields. Since early yields of three out of four cultivars tested in this study decreased significantly with increasing cold stress, we suggest that these cultivars should not be planted in late winter because of yield reductions induced by exposure of transplants to cold stress unless the unit price for earlier watermelons warrants and compensates for the reduced yield expected from lower yields.

\section{Literature Cited}

Bates, M.D. and R.W. Robinson. 1995. Cucumbers, melons, and watermelons, p. 89-97. In: J. Smartt and N.W. Simmonds (eds.). Evolution of crop plants. 2nd ed. Longman Scientific \& Technical, Essex, England.

Bradow, J.M. 1990. Chilling sensitivity of photosynthetic oil-seedlings. J. Expt. Bot. 41:15951600.

Cook, W. 1996. 1996 Agricultural chemical handbook. Clemson Univ. Coop. Ext. Serv. Pub. EC 670

Dufault, R.J. and R.R. Melton. 1990. Cyclic cold stress before transplanting influence tomato seedling growth, but not fruit earliness, fresh-market yield, or quality. J. Amer. Soc. Hort. Sci. 115:559-563.

Graham, D. and B.D. Patterson. 1982. Responses of plants to low, non-freezing temperatures: Proteins, metabolism and acclimation. Ann. Rev. Plant Physiol. 33:347-372.

Hall, M.R., S.R. Ghate, and S.C. Phatak. 1993. Potential of late-planting transplants in an established watermelon field during near-optimal temperatures. Univ. Ga. Agr. Expt. Sta. Bul. 619:1-7.

Hassell, R.L. 1979. The effects of low temperature on the growth of muskmelon and watermelon plants. MS thesis. Cornell Univ.

Hetherington, S.E., R.M. Smillie, A.K. Hardacre, and H.A. Eagles. 1983. Using chlorophyll fluorescence in vivo to measure the chilling tolerances of different populations of maize. Aust. J. Plant Physiol. 10:247-256.

Korkmaz, A. and R.J. Dufault. 2001. Developmental consequences of cold temperature stresses at transplanting on seedling and field growth and yield: I. Watermelon. J. Amer. Soc. Hort. Sci. 126:404-409.

Marini, R.P. 1999. Are nonsignificant differences really not significant? HortScience 34:761-762.

Mizelle, W.O. 1985. Vegetable economics-Planning guide for 1986. Ga. Coop. Ext. Serv. Misc. Pub. 220.

Mizelle, W.O. 1988. Commercial watermelon production. Ga. Coop. Ext. Serv. Bul. B-996.

Pardossi, A., S.S. Lovemore, and F. Tognoni. 1988. The effect of different hardening treatments on tomato seedling growth, chilling resistance, and crop production. Acta. Hort. 226:371-378

Rikin, A., A. Blumenfeld, and A.E. Richmond. 1976. Chilling resistance as affected by stressing environments and abscisic acid. Bot. Gaz. 137:307-312.

Risser, G., P. Carnillon, J.C. Rode, and M. Auge. 1978. Effect de la temperature desracines sur la croissance de jeunes plantes de diverses varietes de melon (Cucumis melo L.). Ann. Agron. 29:453-473.

Sasson, N. and W. Bramlage. 1981. Effects of chemical protectants against chilling injury of young cucumber seedlings. J. Amer. Soc. Hort. Sci. 106:282-284.

Stamp, P. 1987. Seedling development of adapted and exotic maize genotypes at severe chilling stress. J. Expt. Bot. 38:336-1342.

Stewart, J. McD. and G. Guinn. 1969. Chilling injury and changes in adenosine triphosphate of cotton seedlings. Plant Physiol. 44:605-608.

U.S. Dept. of Agriculture. 1978. United States standards for grades of watermelons. U.S. Dept. Agr. Wash., D.C. 